\title{
Print Media and Cultural Identity of Santri: Responses of the Pesantren's Young Leaders in Indonesia
}

\author{
Nor Ismah \\ Leiden University-Institute for Area Studies, Netherlands \\ email:norismahkz@gmail.com
}

\begin{abstract}
The development of Islamic print media that targets youth as readers has challenged pesantren for selecting appropriate reading materials for students according to its values and tradition. This paper aims to examine the dynamics life of pesantren as "fortress for the defense of the Islamic community" in dealing with influences coming from outside of pesantren. Analyzing the responses of young leaders of pesantren to print media (books, novels, and magazines) containing Islamic values and symbols, and targeting Muslim teenagers as their readers and consumers, with focusing on how these media might influence the establishment of the cultural identity of santri. My paper will answer two main questions: how do the young pesantren leaders respond on the emergence of many novels and magazines that come into the pesantren? What are the rules and regulations they introduce to preserve the cultural identity of santri? In dealing with the challenge of print media, most of the pesantren where these young pesantren leaders live have an "exception" regarding book materials as an attempt to form and protect the cultural identity of santri.
\end{abstract}

\section{Keywords:}

Print media, pesantren, and cultural identity of santri

\section{Introduction}

In 1993 when I was at the pesantren (Islamic boarding school) Al-Fathimiyyah-Jombang, East Java, Indonesia, my friend showed me a magazine with a colorful cover, well-known Annida. The magazine compiled Islamic short-stories and other articles that discussed the social 
world of Muslim youth in urban areas. I was very interested to find it due to many magazines I read during semester break were mostly secular magazines, mainly both Anita Cemerlang and Aneka. Meanwhile, Annida offered topics related to a daily activity of how being a good Muslim, such as keeping dignity as Muslim and implementing Islamic principles, especially calling for the right way and preventing the bad things (amar ma'ruf nabi munkar).

My friends and I liked to read Annida's short stories, and I noticed that the stories had influenced the way we wrote for our pesantren's bulletin. For instance, in terms of story themes, previously we wrote short stories about love and secular youth lives, but later we wrote about Muslim urban sociability, student religious organization such as ROHIS, Islamic conversion, Da'wah, and Muslim piety. My experience has shown that santri read magazines, books, and other print media containing different messages, and there is a possibility of transferring knowledge and values through the readings.

Print media is a cultural production which is, according to Bourdieu (2007, 92) emerged from an exacting social context. Print media does not emerge from empty sphere, but it represents and signifies a certain values and culture in society. Parekh $(2008,10)$ points out that beliefs and values become significant bases to define and identify personal identity. Identity then can be represented in different markers and forms according to different beliefs and values. However, knowledge and values brought by print media may not correspond with the knowledge and values that have been introduced and taught in the pesantren. The values may also change the cultural identity of santri that has been maintaining by kiai and pesantren's board members.

Some studies of Muslim youth and print media in Indonesia have discussed about youth from the urban setting, such as the organization of Forum Lingkar Pena (FLP: the Circle Pen Forum) that engage mostly urban young Muslim writers in da'wah through writing (Latifah 2005; Kailani 
2012), the literary work of FLP (Widodo 2008; Arnez 2009) and Indonesian Islamic Chick Lit (Dewi 2011), and the influence of books and movies in shaping the hybrid identity of Indonesian Muslim youth (Hariyadi 2010). Yet my paper attempts to look at the experience of a particular Muslim community called pesantren in dealing with print media. This paper will focus on the response of young leaders (the sons and daughters of kiai) to print media (books, novels, and magazines) that contain Islamic values and symbols and may influence the establishment of the cultural identity of santri. This paper will answer two main questions: (1) how do the young pesantren leaders respond on the emergence of many novels and magazines that come into the pesantren? (2) What are the rules and regulations they introduce to preserve the cultural identity of santri?

This paper is significant for the field of Southeast Asian Studies as an attempt to provide a balance description about pesantren education system in Indonesia, the country with the largest Muslim population in the world. After the bombing attack in Jakarta in 2009, it is found out that a few pesantren is associated with terrorist groups, such as pesantren $\mathrm{Al}$ Mukmin Ngruki, Solo, that is linked to Jama'ah Islamiyah (JI) (Woodward 2010, 30; Munir 2003; Bruinessen 2004). As a result, there is a fear of Islamic radicalism and terrorism and false understanding about pesantren. However, I argue that through print media selection, pesantren make an effort to preserve the cultural identity of santri according to their values and traditions, which are tasamub (tolerance), tawazun (balance), ta'adul (justice), and tawasuth (moderation). This effort also means that pesantren make an attempt to maintain their role as "fortress for the defense of the Islamic community” (Dhofier 1999, xxiv).

Beside of collecting secondary data from the literature and documents, the paper is also completed with the primary data collected through interviews to six young leaders of pesantren, including sons and daughters of kiai, who represent pesantren from many areas of Java 
and Madura, such as from pesantren Assiddiqiyah, Tangerang-Banten; pesantren Maslakhul Huda Pati-Central Java; pesantren An-NurYogyakarta; pesantren Al-Fathimiyyah; pesantren Darussalam, Banyuwangi-East Java; and pesantren An-Nuqayah Madura. The different view of these young leaders taking into consideration from its areas, similarities, and differences rather than generalizing the view of pesantren leaders, and young leaders are considered as represention of the younger generation of pesantren who might determine and influence the formation of the pesantren system in the future. Hereby, this paper started from the sociohistorical background of popular culture and the print media industry in Indonesia and their influences on pesantren, which then followed by data analysis.

\section{Print Media Industry and Popular Culture in Indonesia}

Explaining the term "popular culture", Heryanto (2008, 6) writes that it is "a product of an industrialized society where both of the signifying practices and their observable products (i.e., culture) are produced or performed in a great number." The rise of popular culture in Indonesia was influenced by the reformation era and the development of market industrialization in the 1980s. The reformation era signifies the democratic political system and tightening of the economy. Thus, political change led to new opportunities for the media market, such as the ability to publish without first getting permits and the legalization of cable television (Sen and Hill 2000, 221; Widodo 2008). Through the publication industry, print media has spread out popular culture including literary work, such as novels and compilation of short stories, magazines, and newspaper into the market readers.

Balai Pustaka founded in 1908 by the Dutch colonial government was taken over by Indonesian government after the independence. It was obligated to republish reading material for schools, such as famous novels in order to support the economic weariness of the 1960s. However, it 
seemed not to promise future due to the lack of skills in distribution and promotion as well as the decreasing market since 1995, Balai Pustaka became a partial private publisher in 1996 and soon after was left behind compared to other national's profit-making publishing house. Subsequently, in 1970 Gramedia was founded in Jakarta, and it became the biggest publisher in Indonesia by the 1980s with more than thirty book stores spread nationwide. Gramedia published not only daily newspaper Kompas, but also novels such as Karmila written by Marga T. This novel publication was important in the field of Indonesian authorship as it signified the emergence of the first new-style popular novels with the prospective selling market, and attracted the surfacing of popular authors (Sen and Hill 2000, 22, 23, and 27).

In the 1970 s popular magazines that targeted teenagers, such as Gadis, Kawanku, Hai, and Anita Cemerlang were published, some by the Gramedia group. Through the magazines, popular culture that is mostly associated with Western culture was introduced to Indonesian teenagers. The content of these magazines included up-to-date fashions, music, movies, celebrity gossip, and printed advertisements, and all of these kinds of contents become trend setters in determining the social world of youth in Indonesia (Handajani 2005 and 2008). In terms of books, a serial novel titled Lupus, written by Hilman Hariwijaya, was published for the first time in 1986, and it electrified young readers with its use of prokem language (slang) (Sen and Hall 2000, 33). Among the prominent writers, there were Gola Gong and Zara Zettira who also published their novel remaja (young adult novel). However, in 1990 the novel remaja had to compete with Indonesian private television companies in providing story entertainment; the government created a policy that local drama, sinetron, should be prioritized (Salam 2002, 2). Nevertheless, according to the 1996's book list of IKAPI, the books printed and sold were dominated by fiksi (fiction) genre together with fiksi for school-children. The second category was filled by 'Islam' themes. It is obvious since religious texts 
became the main book published in Indonesia and in the 1990s around 10 percent of the member of IKAPI's publishing houses prioritized Islamic books as their primary publication (Sen and Hill 2000, 29).

Responding to the publication of "popular magazines" and "secular" fictions, Annida started to appear in 1991 offering "an Islamic alternative for the young Indonesian Muslims". The production of this Islamic magazine was prompted by the activists of dakwah movement, Helvi Tiana Rosa and Dian Yasmina Fajri with their well-known group of young Muslim writers called Forum Lingkar Pena (Kailani 2012, 36). Subsequently, Gramedia started translating Western cbicklit novels in the 2000s, and this translation leaded to the publication of Indonesian chicklit and teenlit novels either from secular or Islamic background (Arimbi 2009; Ismah 2011), including novel remaja Islami and novel pop pesantren. The first category refers to life stories of urban young Muslims, while the later covers daily stories of santri in pesantren (Ismah 2011; 2012). Thus, with many kinds of print media products, teen readers have many more alternatives regarding lifestyles or values that they can learn from the readings.

Reflecting on this massiveness of print media industry, it shows the nature of development and effort in creating a profit market as well as disseminating the messages in the contents of print media, including Islamic values. Weintraub (2011, 3-4) argues that the idea of Muslim popular culture is widely appeal to what the majority of Muslim like, and it has now become part of Islamization. The readers from all over Indonesia are attracted by those books, novels, magazines, and newspapers and they can decide what kind of reading they may have. However, this freedom of choice is not the case for pesantren community and the santri who enrolled education in. They have a certain category regarding print media as well as regulation introduced by the leaders within their community members. 


\section{Print Media and Pesantren}

According to Dhofier (1999, xv, 14), pesantren refers to the "Islamic training centers for advanced studies." It is considered the oldest education system in Indonesia. From classical Javanese sources, he finds that Islamic studies were provided by pesantren in the early part of the sixteenth century. Since this period, small pesantren existed in the coastal area of Java, where Islam first came to Indonesia. These earlier schools did not support modern system of education (Azra and Afrianty 2007, 174). In pesantren, kiai (a founder) becomes the most influential person in determining system and development of pesantren. Kiai is like a king with the pesantren as a small kingdom, where he is the only owner of power and authority (Dhofier 1999, 34). In other words, pesantren's characteristics including regulations, program of study, and the type of pupil, depend on the kiai's thought and decision.

Ismah (2012, 282) argues that "writing and authorship play important roles in spreading Islamic thought and traditions" by citing Van Bruinessen $(1994,14)$ who suggests that between the tenth and fifteenth centuries, Muslim scholars from pesantren had been working on writing the essential references of Islamic tradition, which is called kitab kuning. It is considered as an important element of pesatren. It is classical texts written in the old period and consisted of different Islamic subjects (Bruinessen 1994, 1). To be called kitab kuning because of the color of paper used, and it came from the Middle East in the early twentieth century (Bruinessen 1990, 1). Kitab kuning are written in Arabic language by Indonesian ulama such as Nawawi al-Bantani (1896-1897), Ahmad Khatib (1915), and Kyai Mahfuz Termas (1919-1920) who studied in Mecca and taught in Masjid al-Haram. Through their writings, they influenced and inspired the ulama of pesantren in Indonesia (Bruinessen 1994, 20).

The text of kitab kuning can be divided into eight categories which are: “(1) nabwu (syntax) and sarf (morphology) - both are sometimes called ilmu 
alat, (2) figh, (3) usul figh, (4) hadith, (5) tafsir, (6) taubid, (7) tasamnuf and ethics, and (8) miscellaneous texts on tarikh (history of Islam) and balagah (rhetoric)" (Dhofier 1999, 30). Kitab kuning does not relate to popular books because it is not produced in a great number of products. It is mostly displayed in toko kitab (bookshops that only provides this kind of religious literature) and in particular places, such as where it is close to the Muslim community in Indonesia. Many toko kitab sell Arabic books printed in Egypt and Lebanon, but they have limited collections (Bruinessen 1990, 1).

Another category of book used in pesantren is called buku putih (white book) which refers to "the books written in romanized Indonesian." The theme of this varies including Islamic knowledge and literature. However, some of the authors of this book neglect the classical tradition discussed in kitab kuning, and some cases are new interpretation of, the primary sources, the Qur'an and Hadith. This may become the reason why this kind of books is not allowed in pesantren environment (Bruinessen 1990, 1). Buku putih are more industrialized than kitab kuning. They are available in regular book shops, either in metropolitan cities or in small towns where pesantren mostly are located. Popular novels, books, and magazine are included in this category. However, there is an exception regarding literary works in pesantren. One genre called sastra pesantren (pesantren literature) may be accepted because of it represents and obeys Islamic and pesantren values (Munawar 2009).

Jamal D. Rahman, as cited by Ismah (2011, 107; 2012, 283) explains sastra pesantren as a literature that is associated with pesantren in terms of its origin and existence, for instance syair and nazham (poems in Arabic language), its author and its themes or contents. Because of the literature containing knowledge and tradition of pesantren, the authors should have acquaintance, understanding, and familiarity about pesantren (Rahman 2008). Several literary works on pesantren started to appear in the 1960 s. For example, the work of Djamil Suherman, Syu'bah Asa, and Fudoli 
Zaini, concerned to the religious manifestation and expression of love for God, which was connected with esoteric experiences, human ethics, and the glorification of God's universe (Ismah 2011).

Between these two categories, pesantren decided what kind of print media appropriate to be red and produced within their environments. However, the development of education system and the demand of social culture may influence pesantren in this decision. In Indonesia today, there are two classifications of pesantren: salafiyah (traditional) and khalafiyah (modern). Salafiyah maintain the study of traditional Islamic texts as its essential teaching, while khalafiyah includes the national system of education, such as formal school and madrasah (USAID, 8). For example, modern pesantren may allow its students to read any print media either kitab kuning or white book, since its system is more open about new development. In other words, there are consideration and determining factors that may change the acceptance of pesantren regarding print media, both inside and outside of its circumstances.

\section{The emergence of Print Media in the Pesantren}

The numbers of pesantren are established all around Indonesia. According to the data from the Ministry of Religious Affairs 2011, there are 11.389 pesantren in Java. From this number, it seems that pesantren has potential to be profitable market for books, novels, and magazines, particularly those that address young Muslim readers.

Responding to the entrance of Islamic teen novels, Rif'an Nashir says that in some aspects he does not agree with the message brought by the novels. Since the novels tell much about love relationship between male and female, he thinks that most of the stories are not congruent with the message of the Shariah-ethic. For example, a courtship between men and women is considered as disobeying the Islamic ethics. Although the courtship is portrayed in the stories in appropriate way, still it is not 
accepted by the ethic (Nashir 2012). On the contrary, Tutik Nurul Jannah has different thought regarding the emergence of novels and magazines. She says, "This [the emergence of Islamic teen novels] is not problem, because, the problem in our pesantren is how to urge the students to read" (Jannah 2012). Therefore, according to her, the more books or novels come to pesantren, the more students have opportunity to read it. In similar fashion, Zulfi Adriayani (Adriyani 2012) states that the novels and books bring information within which the santri can learn and understand other experiences and knowledge that cannot be found in pesantren. Learning and understanding others will help the santri to broaden their minds and eliminate cultural shock. This knowledge may motivate them to study hard in order to prepare their future after graduated from pesantren. Furthermore, Lina agrees with Tutik and Zulfi, but she emphasizes that santri should have self-ability to utilize their time properly. "So they will not miss to attending pesantren activities because of enjoying reading," (Lina 2012).

Among the young leaders of pesantren, there are different responses between accepting and rejecting the coming of new printing media to pesantren. The print media can be negative since it may bring value that is different from what they teach the students, and thus pesantren try to control or even ban the novels and magazines. The pesantren, where Rif'an lives only accepts novels, for example if they are representing pesantren culture, such as the idea of being modest. Novel pop pesantren (pesantren popular novel) may be considered to read as it tells about stories of young Moslem who live in pesantren. Regarding the messages, instead of portraying kind of young Muslim piety, novel pop pesantren explores the locality of pesantren with moderate value of Islam (Maarif and Ferdhi 2007). This novel was originated and considered as popular form of sastra pesantren (Ismah 2011). 
However, Tutik, Zulfi, and Lina allowed santri to read the print media because there are benefits no matter the values that it brings as they believe in the selfhood of santri and acknowledge the liberation of thinking among them. Two other respondents are Muhammad Faizi and Atina Balqiz Izzah, similarly think positively toward the emergence of novels, magazines, and books. Atina (Izzah 2012) even says: "Supporting reading activity for the students is important. From reading they get benefits of having knowledge and releasing stress because activities in pesantren may be monotonous." Furthermore, Faizi is concerned with the possibility of developing students' reading interest through providing books, novels, and magazines as much as he can.

The responses of these young generations of pesantren may show the possible changes and development in pesantren regarding the new print media. Pesantren is not restricted to only use yellow book as source of knowledge, but also white book which is the product of popular culture. Nevertheless, they cannot deny the new values and cultures brought by the media that may influence to the identity of santri, and pesantren have responsibilities for controlling this influence.

\section{The Effects of Print Media}

Nilsen and Donelson (2009, 26-31) argued that young readers often identify themselves with the characters while reading a novel. Therefore, the main character in teen novels is usually young protagonist who becomes a champion. Bourdieu $(2007,89)$ also explains that what people read, with whom they interact, what education they enroll will influence the establishment of habitus. These two ideas can explain what is happening with Lina's students. According to her, since her students have opportunity to read books, especially novels, she sees some effects that have influenced them. She says: 
"I noticed that the ways they dress up and speak are influenced by what they read. For example, they imitate the way the characters wear trendy jilbab and speak with the language that is not polite for students in pesantren" (Lina 2012).

However, in the same time she also finds positive impacts, for instance, these readings provide the students an example how to develop ideas in writing and the stories give them motivational support in study. "Especially, there is a novel titled Laskar Pelangi ('the Rainbow Group'). After reading it, they are motivated to pursue their high dream." The novel is written by Andrea Hirata (2008), telling about a group of children in Bangka Island. They are from the non-wealthy family and encounter difficulties in their lives, especially in having their primary education. They go to madrasah with lack of facilities and it is far away from their homes. Stories emerge from their experiences and effort in dealing with the obstacles. However, because they are persistence and strongly motivated by their dream, their year-long attempts ended in success. This novel sends a message to the reader i. e: "don't give up".

Tutik emphasizes what Lina said that television and novels can influence the way of speaking, dressing, thinking, and writing of the santri. She gives another example, "After reading Ayat-Ayat Cinta ('the Verses of Love'), polygamy is being spoken by students, and they are interested in going to Egypt for study" (Jannah 2012). This novel is written by Habiburrahman As-Sirazi (2004). In this novel, Fahri, the main character, is a student of Al-Azhar University in Egypt and marries two women, Maria and Aisha. Faizi says that the emergence of Annida magazine gives his students idea in collecting their short stories and publishing them into a magazine (Faizi 2012). Annida is an Islamic magazine addresses young readers published by Forum Lingkar Pena (the pen circle forum) community in Indonesia. The magazine consists of short stories and articles about youth Muslim sociability. The sons and daughters of kiai 
I interviewed find the negative impact of print media. However, as long as the impact does not change the essential identity of santribood in such negative ways, for example, in the way they dress up and behave, it is acceptable.

Furthermore, Zulfi (Adriyani 2012) states that print media may not influence the identity of santri because the pesantren regulations are more powerful and determined to the santribood. Santri have been living within the set of regulation and system run by pesantren, and those are more influential than the new influence brought by print media. Moreover, in her pesantren, there is one regulation regarding print media which is forbidding the students to read novels during the study hours. Meanwhile, Rif'an argues that print media does not have positive impact. "This influence does not support the effort of pesantren in training students to have excellent personalities" (Nashir 2012). Therefore, in Rif'an's pesantren reading any novels and magazines are forbidden. Here, positive and negative effects are being negotiated, but the theme that emerges in this discussion is that there are negative influences that can or cannot be tolerated according to the pesantren tradition.

\section{Pornography, Islamist, and Radicalism}

Returning to the idea that pesantren is the fortress for Muslim community (Dhofier 1999, xxiv), pesantren has to mitigate some negative influences come from out of their values and traditions. Faizi says that his pesantren attempts to eliminate pornography from any print media read by santri because it is considered inappropriate and breaking the pesantren rules regarding sex and sexuality. Therefore, his pesantren forbids secular youth magazines and teen novels that sometimes describe about kissing and hugging, but allow Islamic teen novels and magazines. "Because secular magazines often display pictures of models that do not cover their bodies properly" (Faizi 2012). Similarly, other respondents also share the 
same idea that books, magazines, and novels must be checked whether or not they contain pornography.

Another concern regarding reading materials is the idea of radicalism and terrorism which opposite the pesantren values. Mas'ud (2013) cites a study conducted by Nanyang Technical University (NTUS) in 2010 that shows a list of 102 Islamic boarding schools categorized as radical. Although the method of classification is an object for further clarification, it shows the probability of the existence of radical pesantren. Responding to this matter, Tutik shares:

"In my opinion, reading materials that contain the message of fundamentalism and radicalism, such as Sabili magazine must be supervised. However, so far pesantren never banned the magazine. Why? I guess, because we have not found any student who read any fundamentalist or radical literature" (Jannah 2012).

Faizi has the same thought that books with radicalism message should be looked suspiciously. According to him, however it is unfair if santri are forbidden to read such books because they actually can learn and develop their knowledge from any perspectives. Therefore, in his pesantren there is a short training for new students and those who will graduate about the pesantren values which are tasamuh (tolerance), tawazun (balance), ta'adul (justice), and tawasuth (moderation) (Faizi 2012).

Woodward $(2001,31)$ explains that Islamist groups support "a highly politicized and anti-Western interpretation of Islam." They are mostly found in university campuses and large urban centers. They are involved with the global Moslem discourse focused on jihad and shariah law. Like Islamists elsewhere, they concur in their views of global politics, such a belief in Western attempts to annihilate Islam and that the only solution to the problem is establishing nation-states based on shariah law and global Islamic collaboration. As'ad (2010) suggests that pesantren can play significant role in countering radicalism, especially traditional pesantren 
that are recognized with their moderate thoughts and tradition. Instead of being consumers of media, santri should be producers i.e. writers to disseminate the moderate understanding of Islam.

Currently, pesantren are not only protecting their communities from Western influence through popular culture, but also from radical Islam that may be linked to terrorism. Media, such as book, radio and internet, become an effective mean to spread radicalism. In order to prevent these influences, Lina specifically explains that there are values that her pesantren considers in selecting reading material for the students. These are:

"First, religious values which means that the reading materials must be congruent with Islamic values, although the book is not about religion. Second, moral values which refers to good and bad behavior. Third is the benefit of the reading material which means the benefit for santri, knowledge development, and brain refreshment. The reading should support the formation of santri identity" (Lina 2012).

Tutik also explains that the selection of print media and any program activities implemented in her pesantren considers the objective of pesantren education, which is to produce the sholeh (pious) and akrom (noble) generation. Therefore, any values or culture that does not support its objective should be mitigated, and this effort is determined by the kiai (Jannah 2012). Atina, in the same way, emphasizes that her pesantren are more concerned about pornography, radicalism, and extremism brought by print media. Hence as long as the reading materials do not contain the messages, her pesantren allow the students to read both yellow and white books.

\section{Conclusion}

I have explained the emergence of popular culture and the print media industry in Indonesia that are influenced by the reformation era and the development of market industrialization in 1980s. Print media 
companies such as Balai Pustaka and Gramedia play important roles in creating and maintaining a readers' market in Indonesia with fiction as the largest genre that has been produced. Regarding print media circulated in pesantren, there are two types of books, yellow books and white books. Books that are not written in Arabic on yellow papers and discuss about Islamic classical knowledge are considered white book, a type of books that is rejected by past Islamic scholars. However, this rejection is no longer anymore. Some pesantren have accepted the entrance of white books with certain consideration.

Based on my interviews, most of the pesantren where these young pesantren leaders live appreciate the freedom of thinking and speaking by allowing the students to read any sources of material of yellow and white books. However, they have an exception regarding books that contain pornography and the idea of Islamic radicalism and extremism. Through this exception, pesantren attempts to form and protect the cultural identity of santri from outside influences. In addition, these responses also show that although they live in the same places called pesantren, each pesantren has its own rules depending on the leader and the circumstances where the pesantren is located.

\section{References}

Adriyani, Zulfi. 2012. Questions. E-mail message to informant (March 29) As'ad, Muhammad. 2010. Deradicalization through 'Pesantren'. The Jakarta Post, October 03.

Arnez, Monika. 2009. "Dakwah by the Pen: Reading Helvy Tiana Rosa's Bukavu." Indonesia and the Malay World 37, 107: 45-64.

Azra, Azyumardi., Afrianty, Dina., and Hefner, Robert W. 2007. "Pesantren and Madrasa: Muslim Schools and National Ideals in Indonesia." In Robert W. Hefner and Muhammad Qasim Zaman (Ed.) Schooling Islam the Culture and Politics of Modern Muslin Education. The 
United Kingdom: Princeton University Press.

Bourdieu, Pierre. 2007. "Field of Power, Literary Field, and Habitus." In The Cultural Studies Reader Third Edition, ed. Simon During. New York: Routledge.

Bruinessen, Martin Van. 1990. "Kitab Kuning: Books in Arabic Script Used in the Pesantren Milieu (Comments on a New Collection in the Kitlv Library)." Bijdragen tot de Taal-, Land- en Volkenkunde 146: 226-69.

Bruinessen, Martin Van. 1994. "Pesantren and Kitab Kuning: Maintenance and Continuation of a Tradition of Religious Learning." In Texts from the Islands: Oral and Written Traditions of Indonesia and the Malay World. Ethnologica Bernica 4, ed. Wolfgang Marschall, 121-45. Berne: University of Berne.

Bruinessen, Martin Van. 2002. "Genealogies of Islamic radicalism in postSuharto Indonesia." South East Asia Research 10, 2: 117-154.

Bruinessen, Martin Van. 2004. 'Traditionalist' and 'Islamist' pesantren in contemporary Indonesia. Paper presented at the workshop 'The Madrasa in Asia, transnational linkages and alleged or real political activities', ISIM, Leiden, 24-25 May.

Dewi, Novita. 2011. Formation of Youth Identity in Indonesian Islamic Chick Lit. K@ta 13, 1: 134-146.

Dhofier, Zamakhsyari. 1999. The Pesantren Tradition, The Role of the Kiai in the Maintenance of Traditional Islam in Java. USA: Program for Southeast Asia Studies ASU.

Ditpdpontren. (Direktorat Pendidikan Diniyah dan Pondok Pesantren Kementrian Agama Republik Indonesia). (n.d.) Data Pesantren. Retrieved from http://www.ditpdpontren.com/index. php?option $=$ com_content\&view $=$ article\&id $=76$ :data-pesantren \&catid $=40:$ link\&Itemid $=57$

Faizi, Muhammad. 2012. Questions. E-mail message to informant (March 29).

Handajani, Suzie. 2005. Globalizing Local Girls: The Representation of Adolescents in Indonesian Female Teen Magazines. Unpublished Master thesis, University of Western Australia.

Handajani, Suzie. 2008. "Western Inscriptions on Indonesian Bodies: Representations of Adolescents in Indonesian Female Teen 
Magazines." Intersections: Gender and Sexuality in Asia and the Pacific, 18 October.

Hariyadi. 2010. Islamic Popular Culture and the New Identity of Indonesian

Muslim Youths. A paper presented to the 18th Biennial Conference of the Asian Studies Association of Australia in Adelaide, 5-8 July. Heryanto, Ariel. 2008. "Pop Culture and Competing Identities." In Ariel Heryanto (Ed.) Popular Culture in Indonesia, Fluid Identities in Post-Authoritarian Politics. New York: Routledge.

Ismah, Nor. 2011. "The New Generation of Women Writers from the Pesantren Tradition in Indonesia." Explorations 11, 1: 106-20.

Ismah, Nor. 2012. "Young Women Writers from the Pesantren Tradition: Self Innitiative, Learning Environment and Education System." Journal of Indonesian Islam 6, 2: 279-304.

Izzah, Atina Balqiz. 2012. Questions. E-mail message to informant (March 29).

Jannah, Tutik Nurul. 2012. Questions. E-mail message to informant (March 29).

Kailani, Najib. 2012. "Forum Lingkar Pena and Muslim youth in Contemporary Indonesia." Review of Indonesian and Malaysian Affairs 46, 1: 33-53.

Latifah. 2005. "Writing the Self, Ascribing Islam, Islamic Teen Fiction: Reforming the Moslem". A paper presented in the Singapore Graduate Forum on Southeast Asian Studies organized by Asia Research Institute, National University of Singapore.

Lina. 2012. Questions. E-mail message to informant (March 29).

Maarif, Nurul H. and Gamal Ferdhi. 2007. Teenlit Dari Bilik Pesantren. In Tempo (Jakarta), February 26-March 4.

Mas'ud, Abdurrahman. 2013. Pesantren and Radicalization. Retreived from http://www.thejakartapost.com/news/2013/05/17/ pesantren-and-radicalization.html (accessed on 2013, May 17).

Munawar, Ridwan. 2009. Ledakan Sastra Pesantren Mutakhir: Cinta, Kritisisme, Dan Industri. Retrieved from http://sastra-indonesia. com/2009/03/ledakan-sastra-pesantren-mutakhir-cintakritisisme-dan-industri (Accessed on March 2009).

Munir, Lily Zakiyah. 2003. Nurturing Tolerance in Pesantren. The Jakarta Post. (September 5).

DINIKA, Volume I, Number 3, September - December 2016 
Nashir, Rif'an. 2012. Questions. E-mail message to informant (March 30).

Nilsen, Allen Pace and Kenneth L. Donelson. 2009. Literature for Today's Young Adults. The USA: Pearson.

Rahman, JamalD. 2008. Sastra, Pesantren, Dan Radikalisme Islam. Retrieved from http://jamaldrahman.wordpress.com/2008/10/25/sastrapesantren-dan-radikalisme-islam/

Sen, Krishna and David T. Hill. 2000. Media, Culture and Politics in Indonesia. New York: Oxford University Press.

United States Agency for International Development (USAID). (n.d). Analysis of the Current Situation of Islamic Formal Junior Secondary Education in Indonesia. Retrieved from http://ddpext.worldbank.org/EdStats/IDNdprep07.pdf

Widodo, Amrih. 2008. Writing for God. In Inside Indonesia. Retrieved from http://www.insideindonesia.org/writing-for-god?highligh $\mathrm{t}=$ WyJ3aWRvZG8iLCJ3aWRvZG8ncyJd (Accessed on 2008, 14 September).

Woodward, Mark R. 2001. "Indonesia, Islam, and the Prospect for Democracy." The Johns Hopkins University Press: SAIS Review 21, 2: 29-37.

Woodward, Mark R. 2010. "Inayah Rohmaniyah, Ali Amin and Diana Coleman. Muslim Education, Celebrating Islam and Having Fun As Counter-Radicalization Strategies in Indonesia." Perspectives on Terrorism 4, 4 October.

Weintraub, Andrew. 2011. "The Study of Islam and Popular Culture in Indonesia and Malaysia." In Andrew Weintraub (Ed). Islam and Popular Culture in Indonesia and Malaysia. New York: Routledge. 
DINIKA, Volume I, Number 3, September - December 2016 